\title{
Technical Guidelines for Installation of Rainwater Harvesting System and its Operation
}

Binod Shakya and Jeewan P. Thanju

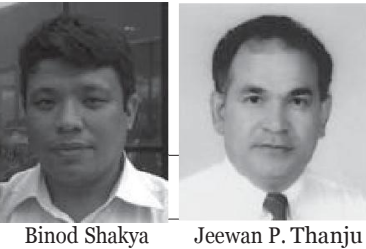

Abstract: Rainwater harvesting (RWH) systems have been in use since ancient times, and these days its use is increasing. However, due to improper planning and design, problems are seen and the collected water is polluted.

The major reason for water contamination is attributed to the toxic materials used for the rain harvesting system, faulty operation, improper rain filtration system and improper disinfection methods. The reason for diseases arising from drinking rainwater is the consumption of contaminated rainwater. Clean raindrops comprising rainwater will become contaminated as they pass through the atmosphere, flow over the roof surface, flow along the gutter, and upon collection and storage.

This paper focuses on the technical guidelines for the installation of RWH components, its operation and maintenance, and rainwater quality improvement for household use.

Key words: Rainwater harvesting, first flush for $\mathrm{RWH}$, disinfection of rainwater, catchment, guidelines for $\mathrm{RWH}$

\section{Background}

D ainwater harvesting (RWH) is being practiced Rin many countries both with good rainfall and also where rainfall is scanty. In countries with good and frequent rainfall such as Myanmar, Thailand, Sri Lanka, Maldives, Pacific islands etc. RWH is practiced. In dry areas with scanty rainfall such as Rajasthan, India and Gansu Province of China, RWH is also being widely used.

The Department for Water Supply and Sewerage (DWSS), Government of Nepal has produced Draft Technical Guidance (TG) on the application and construction of rainwater systems (IDI 2010). The Department of Urban Development and Building Construction has been working since early 2006 on the promotion of rainwater harvesting in the urban areas. The Department has produced a final draft of the RWH Guidelines which are to be used to guide municipal authorities and those engaged in the building trade.

In Nepal the TG prepared by the DWSS has not yet been finalized even after two years of its preparation. As this TG is bulky, it will fruitful to prepare a brief TG after review by related experts.

\section{Why Technical Guidelines is Required}

The performances of the existing RWH system in many places are not satisfactory due to faulty design and installation. It is expected that a TG will help/assist in the smooth construction and operation/maintenance of a RWH system. Further, the rainwater collected have shown the presence of e coliform in large percentages of samples tested.

\section{Evaluation of RWHS}

RWH implemented by the DWSS in 18 districts were evaluated, and the following table 1 is the result (Udaya 2004).

The major reason for the poor quality is due to the toxic material used for the rain harvesting system, its bad operation, improper rain filtration system and

\begin{tabular}{|l|c|c|c|}
\hline \multicolumn{1}{|c|}{ Description } & Excellent & Good & Poor \\
\hline Technical Aspect & $13 \%$ & $57 \%$ & $30 \%$ \\
\hline Institutional Aspect & $4 \%$ & $35 \%$ & $61 \%$ \\
\hline Social/environmental & 0 & $43 \%$ & $57 \%$ \\
\hline Financial Aspect & $14 \%$ & $46 \%$ & $40 \%$ \\
\hline
\end{tabular}

Table 1. Evaluation of RWH Systems

disinfection methods. But it is noted that in ancient rainwater harvesting systems, there was no provision of purifying rain water and ensuring uniformity of the materials used for the harvesting system. Nowadays, rainwater harvesting with a proper health care system is gaining popularity in many developing countries due to shortage of other clean water resources. But still in many countries, particularly the least developed countries, the harvester still ignores the health risk from rainwater.

The main aim of this paper is to give some guidelines for the installation of system components and disinfection of the rainwater mostly for household use.

\section{Water Requirement}

The following criteria were developed for water scarce rural areas of Nepal:

\section{Water Demand Criteria (IDI 2010):}

a. Generally 5-10 litres/capita/day

b. In school, the water demand may be taken as $2-3$ litres/student/ per day

c. Alternative water source but far in distance: potable only source-adopt 5 litres/capacity/day

d. Contaminated water source not suitable for drinking purpose without considerable treatment: consider potable only source-adopt 5 litres/capita/day

e. No water source nearby or source is very far $(>1 \mathrm{~km})$ from settlement-Consider adaptive water source adopt 10 litres/capita/day

f. Availability of seasonal water source but the condition prevails at all other periods as above adopt provision of b, c, and d 


\section{Calculation of Required Water and Available Water}

For accuracy, it is required to acquire monthly rainfall data of the site for about 15 years. The average monthly data should be used to derive 10 day average rainfall. In very small showers, most of the water goes to evaporation/first flush etc. and the recoverable water is almost nil. Hence, small showers should be neglected in the calculation. The 10 day rainfall multiplied by the roof (catchment) area (horizontal) and the runoff coefficient gives the available water. The water balance should be calculated for the water used by the numbers of the family members of the household. In the monsoon season, there may be periods of spill water, if the storage tank is not of sufficient capacity.

\section{A Sample Calculation is shown as follows:}

For quick calculation, available annual water = average annual rainfall (less small winter showers) $\mathrm{x}$ runoff coefficient $\mathrm{x}$ roof area (catchment area)

If annual rainfall is $1500 \mathrm{~mm}$, runoff coeff. for the CGI roof is 0.85 , and factor for reducing small showers is $0.85 \%$, roof area $=40$ sq.m,

Then, water available $=1500 \mathrm{~mm} \times 40 \mathrm{sqm} \times 0.85 \times 0.85$

$=1.5 \times 40 \times 0.85 \times 0.85=43.35$ cubic metres

It is advised to use a simple Excel sheet for water balance calculation based on 10 days water availability and water use.

\section{Sample Water required in a rural area:}

Considering a 7 month water scarce period, per capita consumption of $10 \mathrm{lit} / \mathrm{per}$ capita/day for 6 member family and one big cattle head $=7 \times 30(6 \times 10+30)=$ 18,900 litres $=18.9$ cu.m.

\section{Basic Components of Rainwater Harvesting System}

RWH system is a simple system that collects direct water from rain and is stored in a tank. Rooftop RWH consists of three major components: a catchment area (roof); a delivery system of gutters, down pipes, filters and any first flush device and a storage system (tank). The basic components are:

- Catchment surface (Roof): The rainfall collection surface or simply rain collecting roof,

- Gutters and downpipes: horizontal and vertical rain water channel that helps water run from the roof to the storage tank,

- Leaf Screen, first flush diverters, and roof washer: Components which remove dust, debris and other vegetations before water goes to the storage tank,

- Cisterns: One or more storage tank, and

- Delivery system: Pumped to the end user

\section{a. Catchment (Roof)}

The Roof is an important component in the rainwater harvesting system. It controls the water both quantitatively and qualitatively as the collection of rainwater depends on the roof size and roof material. The quality and quantity of rainwater from different roofs is a function of the roof material, climatic conditions, and the surrounding environment. Generally, a smoother surface is good for both quantity and quality. Therefore, in the rainwater harvesting system component design, the roof material of the building or house is the first choice of the system component. The common materials of interest are metal sheets, ceramic tiles, rock slate and Ferro cement. In recent days, the most suitable and widely used material is corrugated galvanized steel sheets. Galvanizing protects the steel from corroding by coating with zinc compounds. Some remarks are given in Table 2.

Recommended run off coefficient from the catchment is given in Table. 1

These days most of the CGI sheets used for roofing come in color. The paints used for coloring the CGI sheets normally contain lead that is very harmful to human health. This point has not been researched yet. Hence, it is better to use non-colored galvanized CGI sheets.

\section{b. Gutter Sizing}

The correct installation of gutters is most important so that there are no flat areas where debris and water may pool, as these may provide sites for mosquitoes to breed. Standing water can collect insects, attract animals, and catch organic materials, such as leaves. Decaying organic material can ruin the taste and color of the water and cause health problems.

\begin{tabular}{|l|l|}
\hline Roof Material & \multicolumn{1}{|c|}{ Remarks } \\
\hline Metal & $\begin{array}{l}\text { Easily available and less fitting problem. } \\
\text { Lead fitting should be avoided }\end{array}$ \\
\hline $\begin{array}{l}\text { Clay/concrete } \\
\text { tile }\end{array}$ & $\begin{array}{l}\text { To reduce water loss, tiles can be painted or } \\
\text { coated with a sealant }\end{array}$ \\
\hline Slate & sealant must be nontoxic \\
\hline Asbestos & $\begin{array}{l}\text { Cancer from ingested asbestos is very slight } \\
\text { (Campbell 1993). Inhaling asbestos dust } \\
\text { however has sufficiently high risk for getting } \\
\text { cancer. }\end{array}$ \\
\hline
\end{tabular}

The required gutter width and downpipe size adapted from Still and Thomas 2003, Davis and Lambert 2002 is tabulated in Table 3 .

Slope of Gutter: Recommended slope is $0.5 \%$ for $2 / 3$ length and $1 \%$ slope for remaining $1 / 3$ length. Increasing the slope lets through the same size of gutter greater volume of water (IDI 2010).

\begin{tabular}{|c|c|c|c|c|c|c|c|}
\hline $\begin{array}{c}\text { CGI } \\
\text { roofing }\end{array}$ & Concrete & $\begin{array}{c}\text { Cement } \\
\text { tile }\end{array}$ & $\begin{array}{c}\text { Cement } \\
\text { ground }\end{array}$ & $\begin{array}{c}\text { Plastic film cov- } \\
\text { ered with sand }\end{array}$ & $\begin{array}{c}\text { Hand made } \\
\text { tile }\end{array}$ & $\begin{array}{c}\text { Bituminous } \\
\text { road }\end{array}$ & $\begin{array}{c}\text { Natural } \\
\text { slope (soil) }\end{array}$ \\
\hline 85 & 80 & 75 & 53 & 46 & 40 & 68 & $10-18$ \\
\hline
\end{tabular}

Table 1. Runoff Index in Different Surfaces (in percentage) (Except first and last, the data is from Fuxue, Junlan and Yufeng 1999) 


\begin{tabular}{|c|c|c|}
\hline Roof area $\mathbf{~ m}^{\mathbf{e}}$ & Gutter width, $\mathbf{m m}$ & Downpipe, $\mathbf{m m}$ \\
\hline 17 & 60 & 40 \\
\hline 25 & 70 & 50 \\
\hline 34 & 80 & 50 \\
\hline 46 & 90 & 63 \\
\hline 66 & 100 & 63 \\
\hline 128 & 125 & 75 \\
\hline 208 & 150 & 90 \\
\hline
\end{tabular}

Table 3. Guideline for Gutter and Downpipes.

\section{First Flush Diverter}

The amount of rainwater that needs to be removed through first flush diverters varies between different studies. Yaziz, Gunting et al (1989) have noticed 0.5 $\mathrm{mm}$ of rain is needed to wash thermo tolerant coli form (case study in two Malaysian Campus) (WHO 2004), and Coombes, Kuczera and Kalma (2002) found thermo tolerant coli form flushed in $2 \mathrm{~mm}$ rain in Australia. For different roof size the required water to be diverted by first flush is presented in Table 4 (Coombes, Kuczera and Kalma 2002; Yaziz, Gunting et al 1989). Amount of first flush required for flat roof will be considerably more than for the sloping roofing.

\begin{tabular}{|c|c|c|}
\hline $\begin{array}{c}\text { Roof-Catchment } \\
\text { size, me }\end{array}$ & $\begin{array}{c}\text { Water flushing, } \\
\text { litres } \\
\text { Coombes, Kuczera } \\
\text { and Kalma (2002) }\end{array}$ & $\begin{array}{c}\text { Water flushing, } \\
\text { litres } \\
\text { (Yaziz, Gunting et } \\
\text { al 1989) }\end{array}$ \\
\hline 25 & 50 & 12.5 \\
\hline 35 & 70 & 17.5 \\
\hline 45 & 90 & 22.5 \\
\hline 55 & 110 & 27.5 \\
\hline 65 & 130 & 32.5 \\
\hline 75 & 150 & 37.5 \\
\hline 85 & 170 & 42.5 \\
\hline 95 & 190 & 47.5 \\
\hline 105 & 210 & 52.5 \\
\hline 115 & 230 & 57.5 \\
\hline 125 & 250 & 62.5 \\
\hline 135 & 270 & 67.5 \\
\hline 145 & 290 & 72.5 \\
\hline
\end{tabular}

Table 4. Water Flushing from First Flush Diverter.

\section{d. Storage Tank}

In rainwater harvesting systems, the storage tank is usually the most expensive part. A question is which Tank? It is a question that does not have one right answer because there are many different rainwater tanks used in rainwater harvesting. Some of the most popular tanks used in rainwater harvesting are Polyethylene rainwater tanks. These tanks are much-liked because of the various advantages they have. Firstly, they can be used above the ground, are easily movable and can be kept even below the ground. Polyethylene rainwater tanks are also UV resistant, and rather than being heavy and bulky, are very light in weight and easy to carry around. Fibreglass rainwater tanks are another popular type of rainwater storage tank. The biggest advantage they have is that they are resistant to rust and chemical corrosion. Fibreglass rainwater tanks can also withstand extreme temperatures.

The durability, with some remarks on the different types of tank, is shown in Table 5 .

In countries with frequent rainfall for more than one monsoon season, the required storage container is normally small and in the case of dry areas with scanty rainfall, the storage size required is large. In Nepal, more than $80 \%$ of the rain falls in the 3.5 -months monsoon period. Storing water for dry seasons will require a substantial tank size which is an expensive item. In Nepal, a large number of 2000 litre capacity ferrocement tanks were constructed earlier. In recent years, the tank size has been increased to 6,500 litres capacity (one number for one household).

Where there is ground water table at a reasonable depth such as in Kathmandu, it is fruitful to have a small storage tank say 3,000- 4,000 litres capacity, and the spill is sent to recharge the ground water aquifer after filtering.

\section{Contaminants in Rainwater Harvesting System}

The raindrop as it falls from the cloud is very soft and considered to be cleanest of water in nature. Clean raindrop will become contaminated as it passes through the atmosphere, as it flows over the roof surface, as it flows from the gutter, while it is being stored, during collection from storage and during maintenance.

Faecal coli form, viruses, protozoa, algae and helminths are microorganisms more related to disease. All biological pathogens are not harmful to humans; however, most pathogens can be eliminated by chlorination. The most harmful bacteria are faecal coliforms generally found in bird, animal and human faeces. The positive coli form hints that the water is dirty and, with this, it is difficult to say about the presence of harmful pathogens in water. Only a few of the 20,000 species of protozoans cause disease. Some protozoans produce a cyst which allows the organism to survive for a long time. It is a problem for rainwater harvesting systems because the cysts of some species survive after chlorination. Cysts such as Cryptosporidum are very small in size, 4 to 6 microns, and can easily pass through the normal filter. The absolute 1 micron filter only can stop such cysts.

Many of the researchers have been ignoring the effects of lead poisoning. This does not figure in chemical tests of the water samples. Chemical risk is mainly from the roof and other fitting materials. The degree of risk however also depends on maintenance of the RWH system. Source of contamination, illness and some precautions to be taken are shown from Tables 6 through 8 .

\section{Treatment of Rainwater}

The frequently asked questions by rural and urban rainwater harvesters are: Do I need to filter my water? Do I need to disinfect my water? How do I disinfect my water? Regarding these questions no single answer is available for 
rainwater treatment. Generally, the harvester determines which problem their system has and find /choose the cost effective and health friendly method for treatment.

In many cases, rainwater is generally free from chemical contamination if the roof is installed properly and cleaned regularly. The overhanging trees, bushes and wire that allow birds a resting place must be kept away from the roof to minimize the microbiological contamination. However, it is difficult to make a roof completely free from contamination; regular cleaning of the roof and gutter will give less microbiologically contaminated water and one can disinfect by a simple disinfection process. Due to some atmospheric causes, the rainwater $\mathrm{pH}$ may be a little acidic (less than 7). A slight buffering half table spoon of baking soda per 2000 litres of water in the tank will neutralize the acid, if desired.

\section{a. Chlorination}

When chlorine is treated in water, it reacts with compounds in the water. The amount should be enough for a significant amount of chlorine to remain in the water for

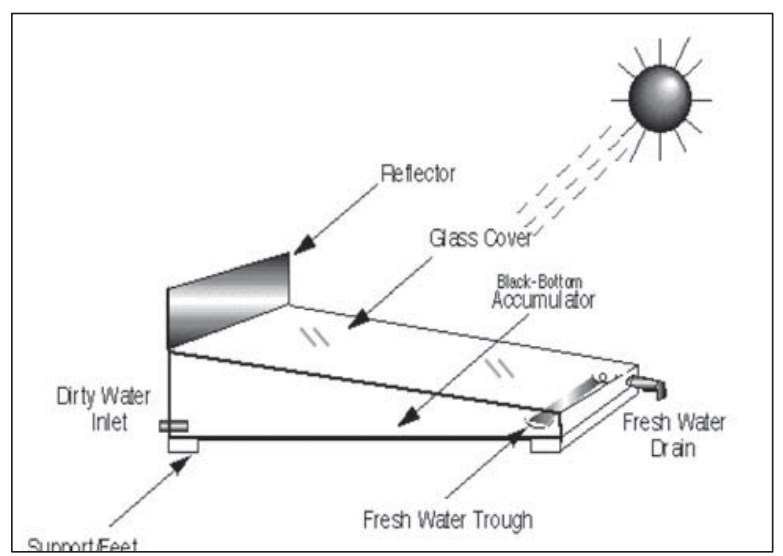

Figure 1. Solar Distiller Model.

which are considered to be inexpensive methods. Solar Water Disinfection (SODIS) improves the microbiological quality of drinking water, using solar UV radiation and temperature to eradicate pathogens causing diarrhoea.

Distillation is one of the many processes that can be used for water purification. This requires an energy input,

\begin{tabular}{|l|l|l|}
\hline \multicolumn{1}{|c|}{ Tank Type } & \multicolumn{1}{|c|}{ Life expectancy } & \multicolumn{1}{c|}{ Remarks } \\
\hline Fibreglass & Minimum 25 years claimed by manufacturer & Tank must be complete with inlet, outlet and overflow \\
\hline Concrete & $\begin{array}{l}\text { If well built with good quality materials and properly } \\
\text { maintained regularly, it can go more than 50 years. }\end{array}$ & $\begin{array}{l}\text { High time consuming in installation and needs open } \\
\text { space. Unmovable and leakage problem may happen. }\end{array}$ \\
\hline $\begin{array}{l}\text { Corrugated gal- } \\
\text { vanized steel }\end{array}$ & $\begin{array}{l}\text { Can be less than } 2 \text { years in corrosive environment. If } \\
\text { well maintained can pull } 20 \text { years of tank life. }\end{array}$ & $\begin{array}{l}\text { Corrosion is the main problem. Inside painting is neces- } \\
\text { sary to extend tank life. }\end{array}$ \\
\hline Plastic/HDPE & Generally 15 to 20 years & $\begin{array}{l}\text { Probability of leakage can be neglected since there will } \\
\text { be no joint in the tank. Light weight }\end{array}$ \\
\hline Ferro cement & $\begin{array}{l}\text { If well built with good quality materials and properly } \\
\text { maintained regularly, it can go } 50 \text { years. }\end{array}$ & $\begin{array}{l}\text { High time consuming in installation and needs open } \\
\text { space. Unmovable and leakage problem may happen. }\end{array}$ \\
\hline
\end{tabular}

Table 5. Life expectancy of Storage Tank (SOPAC 2004).

\begin{tabular}{|l|l|}
\hline \multicolumn{1}{|c|}{ Source } & \multicolumn{1}{c|}{ Reason } \\
\hline $\begin{array}{l}\text { Contamination from the Atmo- } \\
\text { sphere }\end{array}$ & $\begin{array}{l}\text { Rain absorbs pollutants from air. In Maldives most of the islands are far from islands that have in- } \\
\text { dustries. }\end{array}$ \\
\hline Contamination from the roof & $\begin{array}{l}\text { Wind-blown dust, birds, can carry faecal pathogens. Cats and birds also can deposit their own faeces. } \\
\text { Other contaminants such as dust and leaves can be deposited on roofs by wind and birds. }\end{array}$ \\
\hline Contamination from Gutter & $\begin{array}{l}\text { Both PVC and galvanized steel can be used for gutters. Pollutants may deposit if fitted flat or with } \\
\text { insufficient slope. Providing slope in the gutter is necessary to run the water smoothly. Generally an } \\
\text { inclined gutter holds less contaminants. }\end{array}$ \\
\hline Contamination during storage & $\begin{array}{l}\text { The storage tank must be with good quality cover and all openings should be screened. Generally } \\
\text { water quality improves with storage as bacteria and other pathogens gradually die off and other } \\
\text { suspended particles settle in the bottom. }\end{array}$ \\
\hline nance & $\begin{array}{l}\text { The rainwater system may get contaminated by human contact during storage, tank cleaning, screen } \\
\text { cleaning, roof and gutter cleaning. Further, the equipment itself used for cleaning the tanks need to } \\
\text { be clean. }\end{array}$ \\
\hline
\end{tabular}

Table 6. Causes of Rainwater Contamination (Krishna 2005).

disinfection. Chlorine must be present in a concentration of $1 \mathrm{ppm}(1 \mathrm{mg} / \mathrm{L})$ to disinfect the water. The maximum amount of chlorine one can use is $5 \mathrm{mg} / \mathrm{L}$ (WHO).

\section{b. Boiling Rainwater or Solar Treatment}

Boiling of water for at least 5 minutes before drinking is a suitable alternative to get safe drinking water. Boiling water will kill pathogenic viruses, fungi, and bacteria. This method is impractical for large scale boiling and expensive as well.

Solar disinfection or solar distillation is practically possible for treating small amounts of drinking water

\begin{tabular}{|l|l|}
\hline Contaminants & \multicolumn{1}{c|}{ Precaution } \\
\hline $\begin{array}{l}\text { Dust, ash and } \\
\text { other particles }\end{array}$ & $\begin{array}{l}\text { Can be minimized by regular roof and gutter } \\
\text { maintenance and use of proper first flush } \\
\text { diverters. }\end{array}$ \\
\hline $\begin{array}{l}\text { Pathogenic } \\
\text { Bacteria }\end{array}$ & $\begin{array}{l}\text { Can be minimized using first flush diverters } \\
\text { and good roof and regular tank cleaning. }\end{array}$ \\
\hline Heavy metals & $\begin{array}{l}\text { Unless wind blows from industrial area, } \\
\text { heavy metal contamination in water is mini- } \\
\text { mal. Very acidic rain may corrode the toxic } \\
\text { material of the roof. Roof and gutter should } \\
\text { not be fitted with lead material. }\end{array}$ \\
\hline Mosquito larvae & $\begin{array}{l}\text { If tank inlet is well screened, the contami- } \\
\text { nant risk will be low. }\end{array}$ \\
\hline
\end{tabular}

Table 7. Precaution. 
as heat, solar radiation can be the source of energy. In this process, water is evaporated, thus separating water vapour from dissolved matter, which is condensed as pure water.

\section{c. UV Treatment}

Ultra Violet (UV) treatment is the disinfection process of passing water by a special light source that emits UV waves to inactivate harmful micro-organisms. The UV rays alter the nucleic acid (DNA) of viruses, bacteria, or parasites, so that they cannot reproduce and are considered eliminated. UV treatment does not add chemicals or change the chemical composition of the water. But UV treatment does not remove dirt and particles, metals such as lead or iron, or hard minerals such as calcium. Prolonged storage of water after UV treatment is not recommended.

\section{d. Ozone Treatment}

In general, an ozonation system includes passing dry, clean air through a high voltage electric discharge, i.e., corona discharge, which creates ozone concentration of approximately $1 \%$ or $10,000 \mathrm{mg} / \mathrm{L}$.

Ozone is effective over a wide $\mathrm{pH}$ range and rapidly reacts with bacteria, viruses, and protozoans and has stronger germicidal properties than chlorination but the operational cost of ozone treatment is high, and it may be more difficult to find a professional proficient in ozone treatment and system maintenance.

\section{e. Reverse Osmosis (RO) System}

The RO system acts as high pressure water filtration technique. Special membranes are used to remove suspended or dissolved bacterial and chemical impurities up to 1 micron ( 1 micron=1/100omm). Generally, it consists of five stages of filtration to provide clean and micro-organism free soft water for drinking purpose.

The chemical impurities like chlorine are filtered through a Granular Carbon Pre-filter; the suspended impurities present in the inlet water are removed by 5 microns sediment Pre-filter. The extruded Carbon Prefilter also removes bad taste and odor. RO membrane clears the water of bacteria, virus and hardness thus making it safer for drinking. It enhances the taste of water by removing undesirable salts and water.

\section{f. Filtration}

A filter is a type of screen that stops particles when water passes through it. No single filter can disinfect the rain water. Filters with smaller pores trap more debris but such filters slow down the water flow. Most filters do not stop microorganisms. Filters of 1 micron size can stop protozoan cysts. Coarse filters range from 20-30 microns in pore diameter and are generally used to catch larger particles. Coarse filters are not designed to filter out chemicals or pathogens but water filtered from a coarse filter holds less pathogens and could be easily removed through less chlorine or UV treatment.

\section{Some Case Studies \\ Rainwater Harvesting in Maldives}

The Maldives comprises of very small, flat and low-lying coral islands. The highest elevation in the islands is just 2 meters above sea level. Family size in a household consists of about 7.3 people.

The Maldives does not have any surface water such as rivers or lakes; thus, freshwater is a scarce resource for a Maldivian. Nevertheless, almost all the islands of the Maldives do have thin groundwater aquifers. Rain water harvesting is practiced in the Maldives since a long time.

\begin{tabular}{|c|c|c|c|}
\hline \multicolumn{4}{|c|}{ Some Bacteria Caused Diseases Associated with Water } \\
\hline Illness & Sources & Average duration days & Possible Complication \\
\hline Listeriosis & Faecal matter of infected animals & $3-7$ & $\begin{array}{l}\text { Listeric meningitis; headache, stiff neck, } \\
\text { Convulsion; miscarriage. }\end{array}$ \\
\hline Leptospirosis & Urine of infected mamals & $2-5$ & Jaundice, kidney failure, death \\
\hline Campylobacteriosis & $\begin{array}{l}\text { Faecal matter of animals (birds, } \\
\text { domestic and wild) }\end{array}$ & $2-5$ & Arthritis, Guillan-Barre Syndrome \\
\hline Diarrhea & Faecal matter of all animals & 1 & $\begin{array}{l}\text { Hemolytic uremic syndrome which causes } \\
\text { kidney failure }\end{array}$ \\
\hline Enteritis necroticans & Faecal matters of animals & few & Necrotic enteritis \\
\hline Salmonellosis & $\begin{array}{l}\text { Faecal maters of animals includ- } \\
\text { ing bird and reptiles }\end{array}$ & $5-7$ & $\begin{array}{l}\text { Septicemia, death;mostly in infants and } \\
\text { old }\end{array}$ \\
\hline \multicolumn{4}{|c|}{ Some Protozoan Diseases Associated with Water } \\
\hline Giardiasis & Faecal matter of infected animals & Several weeks or months & $\begin{array}{l}\text { Chronic diarrhea with significant weight } \\
\text { loss }\end{array}$ \\
\hline Toxoplasmosis & $\begin{array}{l}\text { Cat, rodent and other animal Fae- } \\
\text { ces }\end{array}$ & $\begin{array}{l}\text { A few days to several } \\
\text { weeks }\end{array}$ & Damage to eye or brain \\
\hline Cryptosporidiosis & Faeces matter of animal & 2 days to 4 weeks & Sever symptoms lasting for months \\
\hline \multicolumn{4}{|c|}{ Some other Diseases Associated with Water } \\
\hline $\begin{array}{l}\text { Hantavirus pulmonary } \\
\text { syndrome }\end{array}$ & $\begin{array}{l}\text { Water contamination from faeces, } \\
\text { urine or saliva from infected species }\end{array}$ & $\begin{array}{l}\text { Onset-2-3 weeks after ex- } \\
\text { posure }\end{array}$ & Severe respiratory failure; even death \\
\hline Alveolar hydatid & Ingesting the tapeworm egg & $\begin{array}{l}\text { Surgical removal and con- } \\
\text { tinuous medication }\end{array}$ & Liver and others \\
\hline
\end{tabular}




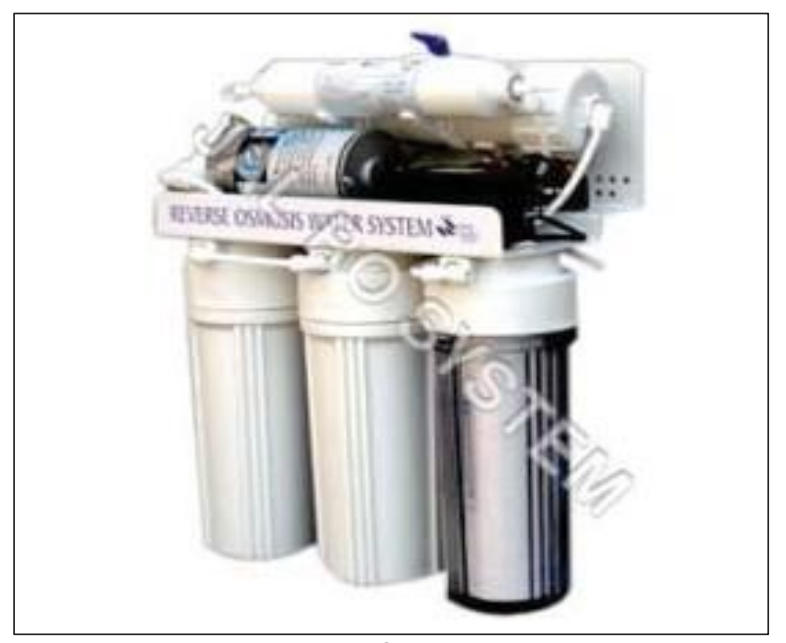

Figure 2. RO Equipment.

Normally, 1000-2000 litre capacity tank size is used in each house for storing rainwater. The Govt. distributes 1000 litres capacity HDPE tanks.

The average annual rainfall is approximately 1900 mm. The Central, Southern and Northern parts of the Maldives receive annual average rainfall of $1924 \mathrm{~mm}$, $2277 \mathrm{~mm}$, and $1786 \mathrm{~mm}$, respectively. Rainfall is evenly distributed throughout the year, except between January and March when dry periods of three months are common (Shakya, Limbu et al 2007 ).

Collected rain water is mainly used for drinking. As people do not like the taste of chlorine; most of the people use rain water for drinking without any disinfection.

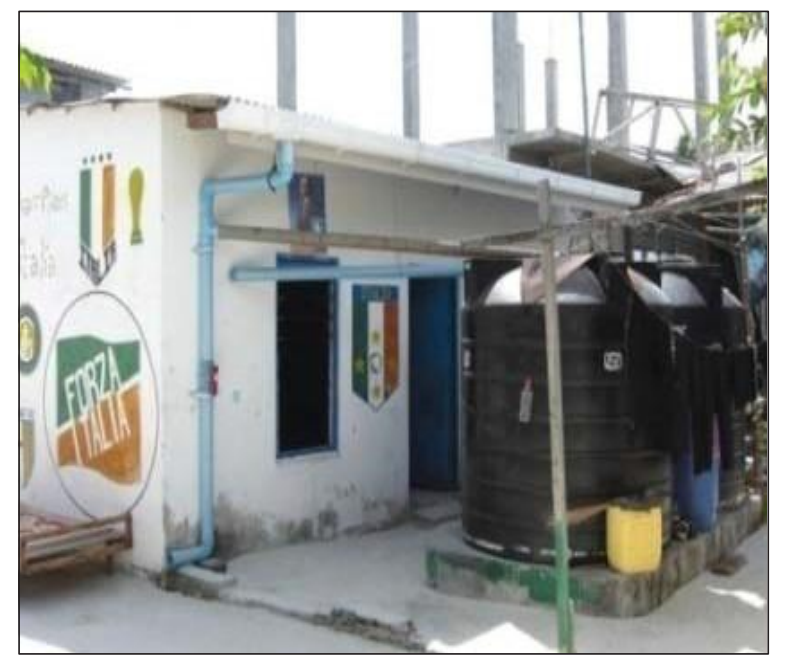

Photo 1. RWH System in the Maldives.

\section{Case Study of Nepal}

In Makawanpur District, Plan Nepal has installed about 609 ferro cement jars of 6,500 liters capacity each. A household is provided with one jar. A performance evaluation was undertaken which shows that about $96 \%$ of households used the collected rainwater for drinking without treatment. Only $2 \%$ practiced boiling before drinking. It was found that $22 \%$ of the samples (2011) and $76.3 \%$ (2009 and 2010) were contaminated with e-coli (NDRI 2011).
The RWH system constructed/promoted by the DWSS in various 18 districts show an unacceptable quality of water (contamination of e-coli) in $90 \%$ of the samples indicating that the first flush systems were not performing well (WETC 2012).

In Nepal, many of the researchers have been ignoring the effects of lead poisoning. This does not figure in the chemical tests of the water samples.

\section{Conclusion}

RWH must be undertaken to augment water supplies wherever feasible. Planning and design should be based on TG. As large percentages of the collected water samples are seen to be polluted with e coli form; proper disinfection is of the utmost necessity.

In Nepal the TG prepared by the DWSS has not yet been finalized even after two years of its preparation. It needs to be finalized after review by the related experts at the earliest.

\section{Acknowledgements}

The field study was carried out in the Maldives to develop guidelines for RWH. It was carried out for the SAARC Coastal Zone Management Centre, Male Maldives and WHO Maldives. The study output was developed as a training manual for SAARC countries.

Further, the second author's writing is based on the experiences in Nepal and the water quality test data used are from the projects of Plan Nepal and DWSS implemented projects.

Binod Shakya, PhD, Professor, Central Department of Hydrology and Meteorology, Tribhuvan Uniersity, Kathmandu, Nepal.

Corresponding address: bshakya.saarc@mail.org

Jeewan P. Thanju, B.Sc. (Civil), M. Engr. has background in water resources. He served in the Nepal's Irrigation Dept. for more the 24 years and was Executive Director of Water Resources Division in Water and Energy Commission Secretariat of Govt. of Nepal. He is a Technical Auditor and has experiences in hydropower studies. Regarding Rainwater harvesting, he has participated International Conferencec on RWH and published several papers in journals and Proceedings of Conferences/workshops. Further, he has field experiences in the installation of the RWH systems. Currently, he is the Editor-in-Chief of HYDRO Nepal Journal and adviser to URJA Nepal, a magazine on energy issues.

Corresponding address: jpthanju@yahoo.com

\section{References}

Coombes, P.J. and G. Kuczera, 2001, Rainwater tank design for water supply and stormwatermanagement. Storm water Industry Association 2001 Regional Conference. Port Stephens, NSW.

Coombes, P.J., G. Kuczera and J. D. Kalma, 2002, 
Economic, water quantity and quality results from a house with a rainwater tank in the inner city. Proceedings of the 27th Hydrology and Water Resources Conference. Melbourne, Australia.

EPA, 1999, Water Quality Sampling Manual, 3rd Edition ISBN o $72426387 \mathrm{X}$ Publication: Environment Protection Agencies, United States (EPA)

Fuxue, Wu; Hunag Junlan and Wu Yufeng, 1999, Planning and Design of Rainwater harvesting Works, Pages 59-71, Water harvesting for Mountain Households in the Hindu Kush-Himalayas, A compliation of Papers presented at the Regional Consultative Meeting held at Chengdu, Sichuan, People's Republic of China, April 9-14, 1997. Published by ICIMOD, Kathmandu, Nepal. Editors: Chalise, Suresh; Prachanda Pradhan; Zhang Xinbao.

Gould, J.C., 1993, Roof runoff as a diffuse source of metals and aquatic toxicity in storm water. Water Science Technology, 28: 317-322.

Gunting, N. Sapiari and A. Ghazali, 1989, Variation in rainwater quality from roof catchments. Water Research, 23: 761-765.

Gurung, R., 2004, Rainwater Harvesting in Soil and its Application on Dry Season Farming, Unpublished Dissertation, T.U.

Krishna, Hari J., 2005, The Texas Manual on Rainwater Harvesting, Third Edition, Texas Water Development Board, Texas. URL:www.twdb.state. tx.us/publications/reports/rainwaterharvestingman ual.3rdedition.pdf.

IDI, 2010, Preparation of Rainwater Harvesting Guideline, IDI Pvt. Ltd, Kathmandu, Dept. of Water Supply and Sewarage, Kathmandu, Nepal, June 2010.

Limbu, B., 2005, Assessment of Rainwater Harvesting Potential in Kathmandu Valley, unpublished dissertation, Schems, Pokhara University, Kathmandu.

Macomber, P. S. H., 2004, Rainwater Catchment Systems for Hawaii, Publication: College of Tropical Agriculture and Human Resources, University of Hawai'i at Mänoa.

Makaju, R., 2007, Roof Rainwater Harvesting: A case study in Bhaktapur, Unpublished dissertation, T.U.

Mosley, L., 2005, Water Quality of Rainwater Harvesting Systems, SOPAC Miscellaneous Report 579.

NDRI, Evaluation of Rainwater Harvesting Program in Makawanpur District, Nepal, 2011, Study undertaken for Plan Nepal, Kathmandu by Nepal Development Research Institue.

Shaheeda, A. I., 2008, Water Supply and Sanitation in Maldives, Paper South Asian Conference on Sanitation.where \& when this conference took place? Shakya, B., B. Limbu, A. Shakya and A. Shakya, 2007, Rain water harvesting Potential in Kathmandu Valley, Journal of Hydrology, SOHAM.

SOPAC, 2004, Guidelines for Harvesting in Pacific Island Countries "Harvesting the Heavens" SOPAC Joint contribution Report.

Udaya, J.V., 2004, Evaluation Report for rainwater harvesting project in Nepal, ERMC \& Udaya JV, 2061.

UNICEF, 2008, Handbook on Water Quality, Published by United Nations Children's Fund, New York.

Waheed, A., 2006, Rain Water Harvesting in the Maldives An Over View, International Workshop on Rainwater Harvesting 27-29, September 2006, Kandy, Sri Lanka.

WETC, Sampling and Testing of Rainwater from Different Rainwater Harvesting Locations, June 2012, Water Engineering \& Training Centre (P.) Ltd., Work undertaken for Dept. of Water Supply and Sewerage, Kathmandu.

WHO, 1996, Guidelines for Drinking Water Quality. Health Criteria and other Supporting Information. 2nd Edition, Vol. 2: 1-6.

WHO, 2004a, Guidelines for Drinking-water Quality, 3rd edition, Volume 1 Recommendations.

WHO, 2004b, Guidelines for drinking-water quality, third edition, incorporating first addendum.

Yaziz, M., Gunting, H., Sapiari, N., Ghazali, A., 1989, Variation in rainwater quality from roof catchments. Water Research 23: 761-765

\section{Bibliography}

www. ces.iisc.ernet.in

www.rainharvesting.co.za

http://www.rain-barrel.net/rainwater-collection.html http://www.rainwaterharvesting.org/policy/legislation.html h t t p : / / w eb.mit . ed u / wat s a n / m ethods waterqualitystandards.html

http://www.rainwaterharvesting.net/

http://www.rainwaterclub.org/downloads.htm

http://www.tn.gov.in/dtp/rainwater.htm

http://www.rainwater-toolkit.net/

http://www.mppcb.nic.in/RWH.htm

http://www.indiawaterportal.org/tt/rwh/

mirkomedia.org/www.irhah20.org/documents.html

http://www.jalvardhini.org/

http://www.epa.gov/safewater/contaminants/index.html

http://www.moppw.gov.np/pdf/Status_of_RWH_in_ Nepal.pdf

\section{CALENDAR OF EVENTS - RAINWATER HARVESTING}

September/October, 2013: International Rainwater Catchment Systems Association Conference. Location: Nanjing, China. More info: http://www.ircsa.org 